Ann. rheum. Dis. (1962), 21, 188.

\title{
INTRA-ARTICULAR STEROID THERAPY IN RHEUMATOID ARTHRITIS
}

\author{
BY \\ J. P. CURRIE AND G. W. MCNICOL \\ From the Rheumatic Diseases Unit, Royal Infirmary, Glasgow
}

The introduction of steroid preparations into joint cavities has become a routine method of treating some cases of rheumatoid arthritis. Murdoch and Will $(1959 a, b)$ have drawn attention to the persistence of prednisolone trimethyl acetate (P.T.M.A.) in the joint cavity and to its, apparently, purely local effect when administered in this way. Since then, Triamcinolone (T.C.A.), Dexamethasone (D.M.), and Betamethasone (B.M.) have been introduced for systemic therapy as high-potency antiphlogistic steroids, and it was natural that these preparations should be adapted for intra-articular use. This investigation concerns an attempt to compare the effects of these newer substances with P.T.M.A.

\section{Material}

All the patients studied were suffering from rheumatoid polyarthritis with marked involvement of the knee joints. The diagnostic criteria were those previously used (Currie, 1952).

\section{Procedure}

The left knee of each patient was treated by the introduction of $50 \mathrm{mg}$. P.T.M.A., and at the same time the right knee was treated by the introduction of $50 \mathrm{mg}$. T.C.A. or $10 \mathrm{mg}$. D.M. or B.M. The joints were then compared under the following headings:

(1) Appearances, including degree of swelling.

(2) Symptoms.

(3) Appearance and viscosity of joint fluid.

(4) Cellular content of joint fluid.

(5) Persistence of steroid in joint fluid. The laboratory procedure for this was precisely as described by Murdoch and Will (1960).

\section{Results}

The results are set out in Tables $I$ to $V$.
TABLE I

SYMPTOMATIC RESPONSE TO THE INTRA-ARTICULAKC INJECTION OF STEROIDS 7 DAYS AFTER TREATMENT

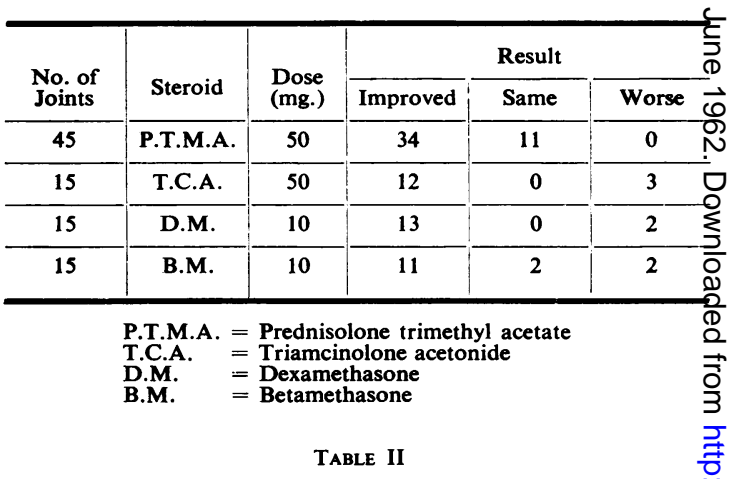

THE OBJECTIVE RESPONSE TO THE INTRA-ARTICULAR INJECTION OF STEROID, 7 DAYS AFTER TREATMENT

\begin{tabular}{|c|c|c|c|c|c|c|c|c|}
\hline \multirow{3}{*}{$\begin{array}{l}\text { No. of } \\
\text { Joints }\end{array}$} & \multirow{3}{*}{ Steroid } & \multirow{3}{*}{$\begin{array}{l}\text { Dose } \\
\text { (mg.) }\end{array}$} & \multicolumn{6}{|c|}{ Result } \\
\hline & & & \multicolumn{2}{|c|}{ Viscosity } & \multicolumn{2}{|c|}{$\begin{array}{l}\text { Volume of } \\
\text { Effusion }\end{array}$} & \multicolumn{2}{|c|}{ Cellularity } \\
\hline & & & + & $0-$ & + & $0-$ & +0 & - \\
\hline 15 & P.T.M.A. & 50 & 15 & 0 & 0 & $\begin{array}{ll}3 & 12\end{array}$ & 00 & \\
\hline 15 & T.C.A. & 50 & 12 & 3 & 3 & $0 \quad 12$ & 30 & 12 \\
\hline 15 & D.M. & 10 & 13 & 20 & 2 & $\begin{array}{ll}0 & 13\end{array}$ & 20 & \\
\hline 15 & B.M. & 10 & 11 & $\begin{array}{ll}40 \\
\end{array}$ & 2 & $\begin{array}{ll}0 & 13\end{array}$ & 20 & 13 \\
\hline \multicolumn{9}{|c|}{$\begin{array}{l}+=\text { Marked increase } \\
0^{+}=\text {No apparent change } \\
-=\text { Marked reduction }\end{array}$} \\
\hline
\end{tabular}

For intra-articular therapy, it is desirable that steroid preparation should fulfil four requirements

(1) It should have high anti-inflammatory or ant $\overrightarrow{\mathbb{B}}$ rheumatic potency. 
(2) A suitable dose should be capable of administration in small bulk.

(3) It should persist in the joint for at least 7 days, since this may be regarded as a minimum interval between treatments.

(4) It should exhibit no irritant properties.

All the steroid preparations used in these trials have been shown to conform to these requirements in experimental work and three of them (P.T.M.A.,

TABLE III

PERSISTENCE OF STEROID IN JOINT FLUID

\begin{tabular}{|c|c|c|c|c|c|c|}
\hline \multirow{2}{*}{ Steroid } & \multirow{2}{*}{$\begin{array}{l}\text { Dose } \\
\text { (mg.) }\end{array}$} & \multirow{2}{*}{$\begin{array}{l}\text { No. of } \\
\text { Joints } \\
\text { in } \\
\text { Trial }\end{array}$} & \multicolumn{4}{|c|}{$\begin{array}{l}\text { No. of Joints with Detectable Steroid } \\
\text { (days) }\end{array}$} \\
\hline & & & 7 & 14 & 21 & 28 \\
\hline P.T.M.A. & 50 & $15^{*}$ & 6 & 0 & 0 & 0 \\
\hline T.C.A. & 50 & 15 & - & 6 & 0 & 0 \\
\hline D.M. & 10 & 15 & - & 5 & 0 & 0 \\
\hline B.M. & 10 & 15 & - & 6 & 1 & 0 \\
\hline
\end{tabular}

- Of the fifteen patients under P.T.M.A., five had T.C.A., five D.M., and five B.M. into the opposite knee.

TABLE IV

PERSISTENCE OF SYMPTOMATIC IMPROVEMENT

\begin{tabular}{lr|c|c|c|c|c}
\hline \multicolumn{1}{r|}{ Steroid } & $\begin{array}{c}\text { Dose } \\
\text { (mg.) }\end{array}$ & $\begin{array}{c}\text { No. of } \\
\text { Joints } \\
\text { in } \\
\text { Trial }\end{array}$ & \multicolumn{3}{|c|}{ No. of Joints Improved } \\
(days)
\end{tabular}

TABLE V

COMPARISON OF EFFECTS OF STEROID PREPARATIONS

\begin{tabular}{|c|c|c|c|c|}
\hline \multirow{2}{*}{$\begin{array}{c}\text { No. } \\
\text { of } \\
\text { Patients }\end{array}$} & \multirow{2}{*}{\multicolumn{2}{|c|}{ Steroid }} & \multicolumn{2}{|c|}{ Effects } \\
\hline & & & Symptomatic & Objective \\
\hline 15 & T.C.A. & $\begin{array}{l}\text { > P.T.M.A. } \\
<\text { P.T.M.A. } \\
=\text { P.T.M.A. }\end{array}$ & $\begin{array}{l}0 \\
3 \\
6\end{array}$ & $\begin{array}{l}0 \\
3 \\
6\end{array}$ \\
\hline 15 & D.M. & $\begin{array}{l}\text { > P.T.M.A. } \\
\text { < P.T.M.A. } \\
=\text { P.T.M.A. }\end{array}$ & $\begin{array}{l}4 \\
2 \\
9\end{array}$ & $\begin{array}{l}7 \\
2 \\
6\end{array}$ \\
\hline 15 & B.M. & $\begin{array}{l}\text { > P.T.M.A. } \\
\text { < P.T.M.A. } \\
=\text { P.T.M.A. }\end{array}$ & $\begin{array}{l}8 \\
2 \\
5\end{array}$ & $\begin{array}{r}12 \\
2 \\
1\end{array}$ \\
\hline
\end{tabular}

$>$ Better than

$<$ Worse than

= Equal to

The patients exhibiting "aggravation reactions" are included in this Table.
D.M., and T.C.A.) in clinical trials (Thompson, 1961; Murdoch and Will, 1960; Hauser, 1960; Dordick and Bernstein, 1959).

Detailed discussion of the results set out in the Tables is unnecessary, but some comment is justifiable on the following points:

Dose.-No claim is made that the doses of steroid used in these trials are optimal or strictly comparable one with another. Roughly, P.T.M.A. and T.C.A. are of equal potency, as are D.M. and B.M. The last two may be regarded as being about ten times as powerful as the others when administered systemically. Thus, the "antirheumatic" effect of the doses administered should have established an advantage of approximately 2 to 1 in favour of D.M. and B.M. The doses, however, were the smallest which allowed of subsequent detection in joint fluid samples.

Degree of Improvement.-Table IV indicates the persistence of symptomatic response to the steroid used.

Table V shows the symptomatic preferences expressed by 45 patients and compares these with the objective findings of $(a)$ reduction in cell count of the joint fluid, $(b)$ reduction in volume of effusion, and (c) increase in fluid viscosity. As expected, the comparatively larger doses of D.M. and B.M. are reflected in the objective findings. To a less marked degree, this is seen also in the symptomatic response. Seven patients preferred P.T.M.A. to the alternative treatment, which produced, in these seven cases, a marked relapse.

"Aggravation Reaction."-Tables I and II show that three joints receiving $50 \mathrm{mg}$. T.C.A., two joints receiving $10 \mathrm{mg}$. D.M., and two joints receiving $10 \mathrm{mg}$. B.M. became markedly worse after the introduction of the steroid preparation. In all these there was a latent period of 12 to 24 hours when the joints appeared to be relieved or at least no worse, but this was followed by rapid onset of pain, and increased swelling and tension of the joints, which lasted for 5 to 10 days. Aspiration of the joints during this period showed that the very copious watery effusion contained a great deal of debris and increased cellular content but no organisms. In all cases, aspiration produced marked relief of symptoms.

It is interesting that the opposite knee joint in each of these patients had received $50 \mathrm{mg}$. P.T.M.A. at the same time, and that this had been followed by relief of symptoms and reduction in effusion. Whether these reactions were due to the vehicle for the steroid or to abnormal sensitivity on the part of some patients, is not clear. 
Persistence of Steroid in Joint Fluid.-The small amounts of steroid used in these trials made their subsequent demonstration in joint fluid difficult (Table III). At least $10 \mathrm{ml}$. joint fluid was required, and, where the effusion rapidly disappeared as a result of treatment, this was not always obtainable. It appears, however, that all the preparations used can probably survive for at least 7 days. Using only the Porter-Silber reaction (Silber and Porter, 1954), reducing steroids could be demonstrated in some joints for up to 21 days after injection. The variation noted in the survival times of the compounds may be related not only to their rates of utilization and degradation, but also to the particle size of the preparations used. This problem is presently being investigated by Dr. G. Will.

\section{Summary}

All four preparations used in this trial are capable of producing marked and sustained response in rheumatoid knees. The degree of symptomatic relief and of objective improvement appeared to be roughly proportional to the dose and potency of the preparation. Betamethasone appeared to have a definite advantage over both the Dexamethasone and the Triamcinolone preparations used. The prednisolone trimethyl acetate preparation used was, however, notably free from any aggravation reaction.

We are indebted to Messrs. Squibb for the Triamcinolone, Messrs. Roussel for the Dexamethasone, Messrs. Glaxo for the Betamethasone, and Messrs. Ciba for the Prednisolone trimethyl acetate, used in this trial.

We should also like to express our thanks to Dr. C. L. Howett and Dr. G. F. Woods of Organon Laboratories for their technical advice and help.

\section{REFERENCES}

Currie, J. P. (1952). Lancet, 2, 15.

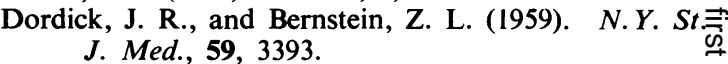

Hauser, E. D. W. (1960). J. Amer. med. Ass., 173, 487음

Murdoch, W. R., and Will, G. (1959a). Brit. med. J.흠 $1,126$.

(1959b). Ibid., 1, 1271

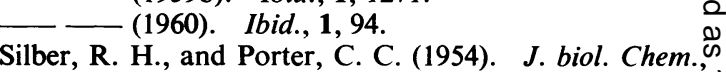
210, 923.

Thompson, M. (1961). Ann. phys. Med., 6, 10.

Stéroïdes intra-articulaires dans l'arthrite rhumatismalệ̀

\section{RÉSUMÉ}

Les quatre préparations employées dans cet essai son capables de produire une réponse marquée et soutenue dans des genoux rhumatismaux. L'intensité du soulagement symptomatique et de l'amélioration objective semblait être plus ou moins proportionnelle à la dose ef à la puissance de la préparation. La bétamethasonesemblait être définitivement plus avantageuse que les préparations de dexamethasone et de triamcinolone usées. Toutefois, la préparation d'acétate de trimethyl prednisolone employée ici s'est caractérisée par unछ̋ absence notable de toute réaction d'aggravation.

Terapéutica intra-articular con esteroides en artritis reumatoide

\section{SUMARIO}

Las cuatro preparaciones usadas en este ensayo son capaces de producir una marcada y sostenidå respuesta en rodillas reumáticas. El grado de aliviơ sintomático y de mejora objetiva apareció ser más of menos proporcional a la dosis y potencia de la pre paración. Betametasona parecía tener una definitiva ventaja sobra las preparaciones de dexametasona y de triamcinolona usadas. Sin embargo, un preparado de acetato de trimetil prednisolona fué notablementę exento de cualquier reacción de agravación. 